\title{
ASSESSMENT OF CELLULAR DAMAGE BY COMET ASSAY AFTER PHOTODYNAMIC THERAPY IN VITRO
}

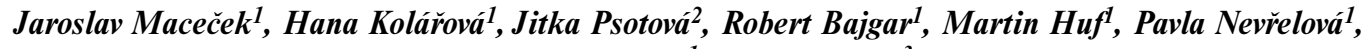 \\ Marek Tomečka ${ }^{1}$, Jiři Mosinger ${ }^{3}$
}

Palacky University in Olomouc, Faculty of Medicine, Czech Republic: Department of Medical Biophysics ${ }^{1}$, Department of Medical Chemistry'; Charles University in Prague, Faculty of Science, Czech Republic: Department of Inorganic Chemistry $^{3}$

Summary: The aim of this study was analysis of DNA damage in the cell line of the human melanoma G361 after photodynamic therapy (PDT) by comet assay. Photodynamic therapy is based on cytotoxic action of sensitizers (10 $\mu \mathrm{M}$ $\mathrm{ZnTPPS}_{4}$ fixed into $1 \mathrm{mM}$ cyclodextrin $\mathrm{hp} \beta C D$ ) and light with a suitable wavelength. Single-cell gel electrophoresis (SCGE, comet assay) is a rapid and sensitive method for detecting DNA strand breaks at the level of single cells. Great amount of DNA damage was detected with the dose of irradiation of $0.1 ; 0.5 \mathrm{~J}$ and $2.5 \mathrm{~J} . c m^{-2}$. Only radiation dose of visible light in the presence of sensitizers can induce DNA breaks of tumour cells. Cells with DNA damage appear as fluorescent comets with tails of DNA fragmentation. In contrast, cells with undamage DNA appear as round spots, because their intact DNA does not migrate out of the cell.

Keywords: Comet assay; Photodynamic therapy; Sensitizer; DNA damage; Cyclodextrine (CD)

\section{Introduction}

The Comet assay provides a very sensitive method for detecting strand breaks. It is based on the alkaline lysis of labile DNA at the damaged sites. Cells are immobilized in thin agarose matrix and placed on the microscope underlying slides and subsequently lysed by alkaline buffer. When subjected to electrophoresis, the unwound, relaxed DNA migrates out of the cells. After staining by nucleic acid stain, we can distinguish between undamaged and damaged cells using inverted fluorescent microscopy in dependence of the dose of irradiation.

Photodynamic therapy is new and promising modality for selective irradiation of malignant neoplasms especially superficial skin cancer (1). It is based on cytotoxic action of sensitizers in the oxygen-rich environment. Sensitizers are organic dyes that bound to a cell and are excited by light source with a suitable wavelength. The majority of sensitizers are relatively lipophilic and are reported to localize predominantly in the cytoplasm or cytoplasmatic organelles (2). The sensitizer molecules lose their energy after absorption of a quantum of light by transferring to oxygen forming singlet oxygen $\left({ }^{1} \mathrm{O}_{2}\right)$. The singlet oxygen is very reactive and rapidly reacts with a number of biological molecules, including membrane lipids, proteins and nucleic acids. The changes in their structure often trigger apoptosis (programmed cell death). Detection of apoptotic cell death in the single cells and tissues has become of paramount importance in many fields such as cancer biology. Apoptosis together with necrosis of tumour cells is expected as a therapeutic effect in photodynamic therapy (3). A potential benefit of PDT is that it causes minimal damage to healthy tissue.

Melanoma cells are cultivated with sensitizer ZnTPPS $_{4}$ [(zinc(II)-5,10,15,20-tetrakis(4-sulphonatophenyl) porphyrine] fixed in cyclodextrin carrier $h p \beta C D$. These substances create complexes with good penetration through the cell membrane. After sensitizer uptake the cells are excited by appropriate light and marked by fluorescent dye (4). The goal of this presented work was investigation of efficiency of photodynamic therapy by means of comet assay.

\section{Material and methods}

About 2 million cells of human melanoma (cell line G361) were cultivated in DMEM with $10 \mu \mathrm{M}$ ZnTPPS $_{4}$ and $1 \mathrm{mM} \mathrm{hp} \beta \mathrm{CD}$ for 48 hours at $37{ }^{\circ} \mathrm{C}$. Then the growth medium was replaced by fresh medium without sensitizer and cells were irradiated by visible light at room temperature. The doses of irradiation were $0.1 ; 0.5 ; 2.5 ; 12.5$ and 60

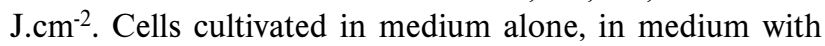
sensitizer and without sensitizer with the maximum dose of 


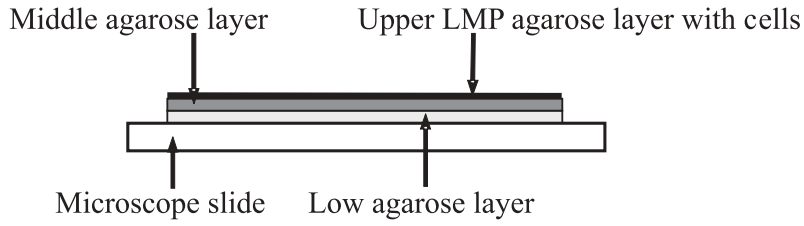

Fig. 1: Diagram of a comet slide.

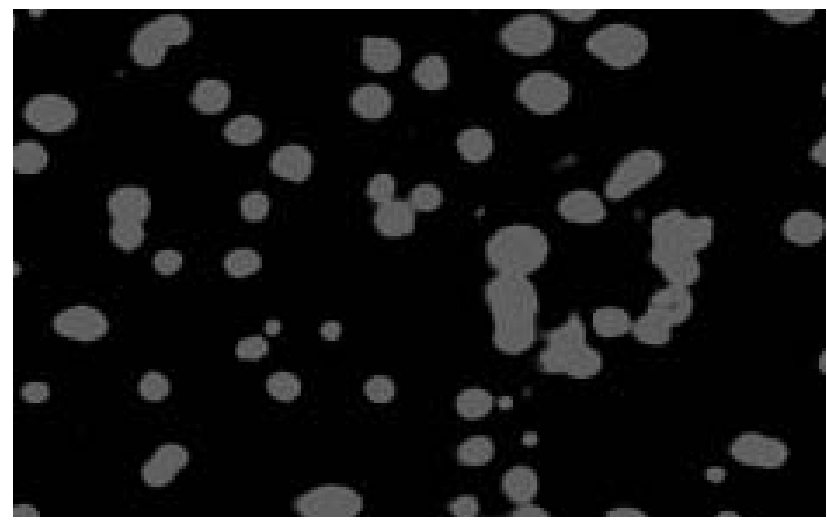

Fig. 3: Typical picture of the undamaged DNA in control samples (G361 cells).

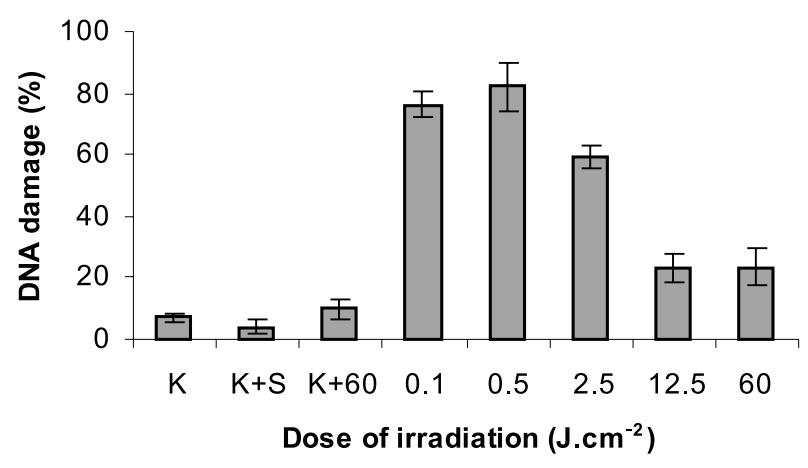

Fig. 5: Percentage occurrence of DNA damage in the dependence of the irradiation dose $(\mathrm{K}=$ control; $\mathrm{S}=$ sensitizer $)$.

irradiation were used as the controls. Other cells were cultivated in medium with sensitizer and were irradiated by different light dose. After irradiation cells were cultivated for next 24 hours at $37^{\circ} \mathrm{C}$ and after this period their damage was assessed by comet assay.

On the microscope slides precoated with $1 \%$ standard agarose in $\mathrm{H}_{2} \mathrm{O}$ were applied $85 \mu \mathrm{l}$ of $1 \%$ standard agarose in PBS and, while still liquid, covered with a cover slip. Slides were placed in fridge for at least $5 \mathrm{~min}$ to solidify agarose. Cells were trypsinated, collected by centrifugation and dispersed in $2 \mathrm{ml}$ PBS by vortexing. $20 \mu \mathrm{l}$ of this solution $\left(2.10^{4}\right.$ cells $)$ was added to $85 \mu$ of $1 \%$ LMP agarose in PBS at $37^{\circ} \mathrm{C}$. Finally $85 \mu \mathrm{l}$ of the mixture were transferred on each slide (Fig. 1) and placed to the fridge for next $5 \mathrm{mi}-$

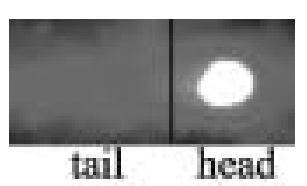

Fig. 2: DNA breaks represented by comet.

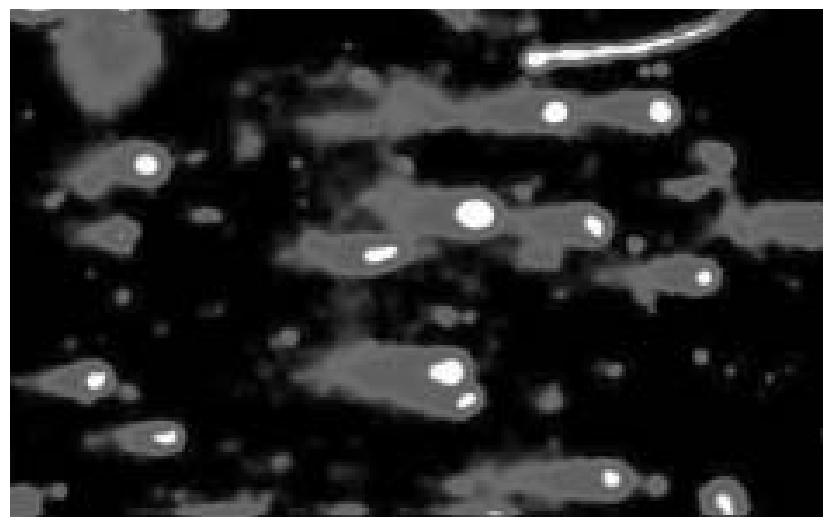

Fig. 4: DNA breaks represented by comets. (PDT of G361 cells; irradiation dose $0.5{\mathrm{~J} . \mathrm{cm}^{-2}}^{-2}$.

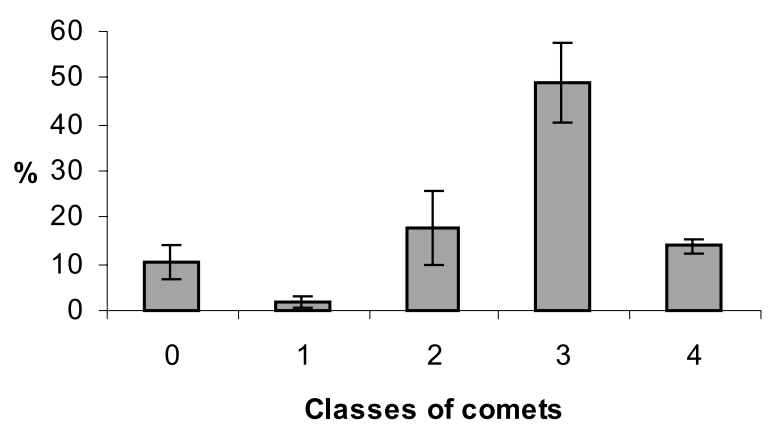

Fig. 6: Percentage occurrence of different stages of DNA

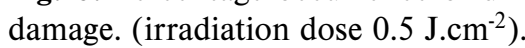

nutes. Microscope slides were immersed in lysis buffer $(2.5$ $\mathrm{M} \mathrm{NaCl}, 100 \mathrm{mM}$ EDTA, $10 \mathrm{mM}$ Tris and 1\% Triton X-100; $\mathrm{pH}=10)$ at $4^{\circ} \mathrm{C}$ for 1 hour. Slides were gently placed on platform in electrophoretic tank and immersed in cool electrophoresis solution ( $300 \mathrm{~mm} \mathrm{NaOH}, 1 \mathrm{mM}$ EDTA) for 40 minutes. Electrophoresis was run 30 minutes at $2.5 \mathrm{~V} . c m^{-1}$. After electrophoresis the slips were washed $3 \times 5$ min with buffer $(0.4 \mathrm{M}$ Tris; $\mathrm{pH}=7.5)$ at $4^{\circ} \mathrm{C}$ and stained by ethidium bromide $(20 \mu \mathrm{g} / \mathrm{ml})$ for the visualization of DNA comet.

It is possible to analyse comets representing different levels of DNA damage quantitatively without image analysis software according to standard method (5). This method classifies comets into classes from class 0 (undamaged, no 
discernible tail) to class 4 (almost all DNA in tail, insignificant head) (5). Each comet (Fig. 2) is given based on its pattern a value according to level of DNA damage. We worked with fluorescent microscope, CCD camera and Olympus Micro Image software.

\section{Results}

The control samples were used to detect undamaged DNA (Fig. 3). In Fig. 4 we can see DNA of cancer cells as comets visualised by ethidium bromide. Belong to great amount of DNA damage representing by comets from class 1 to 4 was detected at the irradiation dose of 0.5 , followed by

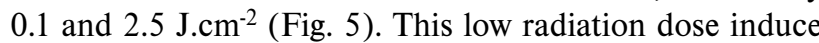
DNA breaks, which correspond to comets belonging to class 3, less 2 and 4 (Fig. 6).

\section{Discussion and conclusions}

Assessment of cellular damage by comet assay is valuable method for detecting DNA breaks. Irradiation of cells can result in a few kinds of reaction. Very low dose of irradiation have no large damage effect on target cells. On the other hand high dose of irradiation cause cell death via necrosis. The major effort of PDT in the field of cancer diseases is to induce cell death mediated by apoptosis. The apoptotic mechanism accompanies DNA fragmentation. The comet assay seems to be good and mainly rapid method to detect DNA cleavage. Moreover our results shows that low radiation dose of visible light $\left(0.1-0.5{\mathrm{~J} . \mathrm{cm}^{-2}}^{2}\right.$ can be use for PDT of tumour cell line G361 using as the sensitizer molecular complex $10 \mu \mathrm{M} \mathrm{ZnTPPS}_{4}$ with $1 \mathrm{mM}$ cyclodextrin carrier hp $\beta C D$.

\section{Acknowledgement}

This work was supported by the grant project of the Grant agency of Czech Republic No. 203/02/1483 and Ministry of Education MSM No. 153100008.

\section{References}

1. Agarwal R, Korman NJ, Mohan RR et al. Apoptosis is an early event during phthalocyanine photodynamic therapy-induced ablation of chemically induced squamous papilomas in mouse skin. Photochem Photobiol 1996;63(4):547-52.

2. McNair FI, Marples B, West CML, Moore JV. A comet assay of DNA and repair in K562 cells after photodynamic therapy using haematoporphyrin derivate, methylene blue and meso-tetrahydroxyphenylchlorin. Br J Cancer 1997;75(12): $1721-9$

3. Kessel D, Luo Y. Initiation of apoptosis versus necrosis by photodynamic therapy with chloroaluminium phtalocyanine. Photochem Photobiol 1997;66(4): 479-83.

4. Mosinger J, Kliment V, Sejbal $\mathbf{J}$ et al. Host-guest complexes of anionic porphyrin sensitizers with cyclodextrins. J Porphyrins Phtalocyanines 2002;6:513-25.

5. Piperakis MP, Visvardis EE, Tassiou AM. Comet assay for nuclear DNA damage. Methods Enzymol 1999;269(20):184-94.

Mgr. Jaroslav Maceček, Palacky University in Olomouc, Faculty of Medicine, Department of Medical Biophysics, Hněvotínská 3, 77515 Olomouc, Czech Republic. e-mail: macecele@tunw.upol.cz 